\section{In Vitro Cytotoxicity Test and Surface Characterization of CoCrW Alloy in Artificial Saliva Solution for Dental Applications}

Klester Santos Souza ${ }^{1}$, Ruth Flavia Vera Villamil Jaimes ${ }^{2}$, Sizue Otta Rogero ${ }^{3}$, Pedro Augusto de Paula Nascente ${ }^{4}$, Silvia Maria Leite Agostinho ${ }^{1}$

In order to evaluate its application as a dental prosthesis material, a CoCrW alloy was subjected to in vitro cytotoxicity test, surface characterization and electrochemical studies performed in artificial saliva and $0.15 \mathrm{~mol} . \mathrm{L}^{-1} \mathrm{NaCl}$ medium. The used techniques were: anodic polarization curves, chronoamperometric measurements, electrochemical impedance spectroscopy (EIS), scanning electron microscopy (SEM), energy dispersive X-ray spectroscopy (EDS) analysis and X-ray photoelectron spectroscopy (XPS). Cytotoxicity test was also performed. The electrochemical behavior of $\mathrm{CoCrW}$ alloy was compared in both studied media, from corrosion potential $\left(\mathrm{E}_{\text {corr }}\right)$ to a $600 \mathrm{mV}$ anodic overvoltage. From the electrochemical measurements it was observed that the CoCrW alloy in both media presents only generalized corrosion. SEM and EDS analysis showed that the alloy presents carbide niobium and silicon and manganese oxides as nonmetallic inclusions. XPS results indicated that cobalt does not significantly contribute to the passivating film formation. Cytotoxicity test showed no cytotoxic character of CoCrW alloy. These results suggest that the CoCrW alloy can be used as biomaterial to be applied as prosthesis in dental implants.

\author{
'Institute of Chemistry, USP \\ - Universidade de São Paulo, \\ São Paulo, SP, Brazil \\ 2UFABC - Universidade Federal do \\ $\mathrm{ABC}$, Santo André, SP, Brazil \\ 3IPEN - Instituto de Pesquisas \\ Energéticas e Nucleares, \\ São Paulo, SP, Brazil \\ ${ }^{4}$ Department of Materials Engineering, \\ UFScar - Universidade Federal de \\ São Carlos, São Carlos, SP, Brazil
}

Correspondence: Silvia Maria Leite Agostinho, Av. Prof. Lineu Prestes, 748, 05508-900 São Paulo, SP, Brazil. Tel: +55-11-3091-2157. e-mail: smlagost@iq.usp.br

Key Words: CoCrW alloy, surface characterization, cytotoxity, dental materials.

\section{Introduction}

Metal alloys have been used since the beginning of the $20^{\text {th }}$ century as material in dentistry due to their mechanical properties $(1,2)$. Nowadays, due to economic issues, non-precious alloys are replacing noble alloys in dentistry. Dental non-precious metal alloys present a thin passive film of oxide on the surface. This passive film must have high adhesion, be compact, present high electrical resistance and absence of defects such as cracks $(1,2)$.

The oral environment is perfect to promote the oxidation of metallic materials. Factors like quantity and quality of saliva, salivary $\mathrm{pH}$, dental plaque, amount of protein, chemical and physical properties of food and fluid intake, and general oral health conditions may influence the metal corrosion in the oral cavity (3). There are two concerns about dental materials in oral environment: the localized effects or systemic damage caused by the release of corrosion products to the body and the effects on the physical properties and clinical performance of the alloy (4-7).

CoCr-based alloys have been utilized in dental prosthesis, since they offer good resistance to corrosion $(8,9)$. Recently, alloys with high content of tungsten instead molybdenum have been developed aiming a better ceramicmetal adhesion (10). On the other hand, the CoCrMo alloys have been more studied (4-12) than CoCrW alloys $(13,14)$.
In this work, in vitro cytotoxicity test, surface characterization and electrochemical behavior of a $\mathrm{CoCrW}$ alloy have been performed in artificial saliva and 0.15 mol. $\mathrm{L}^{-1} \mathrm{NaCl}$ medium in order to evaluate its application as dental prosthesis material. For characterizing the alloy surface, polarization curves, chronoamperometry, electrochemical impedance spectroscopy (EIS), scanning electron microscopy (SEM), energy dispersive X-ray spectroscopy (EDS) and X-ray photoelectron spectroscopy were used. In vitro cytotoxicity test was also performed to study the biocompatibility of the proposed alloy as implant material.

\section{Material and Methods}

\section{Sample and Solutions}

The chemical composition of the CoCrW alloy is in Table 1.

The compositions of the artificial saliva were prepared from three different solutions. The following reagents/concentrations (mol. $\mathrm{L}^{-1}$ ) were used: solution $\mathrm{A}$ :

Table 1. Chemical composition of CoCrW alloy (wt $\%$ )

\begin{tabular}{ccccccccc}
\hline Sample & $\mathrm{Co}$ & $\mathrm{Cr}$ & $\mathrm{W}$ & $\mathrm{Nb}$ & $\mathrm{V}$ & $\mathrm{Si}$ & $\mathrm{Mo}$ & $\mathrm{Fe}$ \\
\hline $\mathrm{CoCrW}$ & 59.4 & 24.5 & 10.0 & 2.0 & 2.0 & 1.0 & 1.0 & 0.1 \\
\hline
\end{tabular}


$\mathrm{NaH}_{2} \mathrm{PO}_{4} / 0.233+\mathrm{KCl} / 1.164+\mathrm{NaCl} / 0.123+\mathrm{NH}_{4} \mathrm{Cl} / 0.205$ + sodium citrate/3.74 $\times 10^{-3}$ + lactic acid/0.039; solution B- urea/0.167 + uric acid/4.46× $10^{-3}+\mathrm{NaOH} / 5 \times 10^{-3}$ and solution C: KSCN/0.123. The saliva solution was prepared daily by mixing $A, B$ and $C$ solutions $(1: 1: 1)$ and then diluted 50 times in high-purity de-ionized water (15).

All the experiments were performed in triplicate with naturally aerated solution at $(37.0 \pm 0.5){ }^{\circ} \mathrm{C}$ and a $6.6 \mathrm{pH}$ (oral conditions).

\section{Electrodes}

The CoCrW alloy working electrodes were discs fabricated from the central part of the bars and had an area of $0.90 \mathrm{~cm}^{2}$. A cylindrical epoxy-base was fitted with the steel disk. A concentric brass rod was coupled to the steel+epoxy-base. The electrodes were prepared by polishing with successively finer grades of emery papers of 120,400, 600 and 2000 mesh and then thoroughly rinsed with distilled water and ethanol and air dried prior to the experiments.

The auxiliary electrode consisted of a platinum foil and it was cleaned with acid and flamed just before each experiment. Saturated calomel electrode (SCE) was used $\dot{s}$ as reference electrode.

\section{Electrochemical Experiments}

The corrosion resistance was evaluated by potentiodynamic polarization anodic curves and chronoamperometric curves. The studied CoCrW alloy was in artificial saliva and 0.15 mol. $\mathrm{L}^{-1} \mathrm{NaCl}$ solutions. These evaluations were performed after the attainment of a constant current at each potential application, starting from the open circuit potential in the anodic direction from $E_{\text {corr }}$ till $0.9 \mathrm{~V}$ vs. SCE using $1 \mathrm{mV} . \mathrm{s}^{-1}$ scan rate. As working criterion, it was assumed that the transpassivation potential is reached when the current density is $10 \square \mathrm{A} /$ $\mathrm{cm}^{2}$. The electrochemical impedance spectroscopy (EIS) measurements were performed over eight frequency decades (from $100 \mathrm{KHz}$ to $10 \mathrm{mHz}$ ). The potential was $\pm 8 \mathrm{mV}$, p.p. The experiments were conducted at $37^{\circ} \mathrm{C}$. A $\mu$ Autolab type III/FRA2 potentiostat (Metrohm Autolab BV, the Netherlands) was used coupled to a frequency response detector and to a microcomputer.

Table 2. Different surface regions analyzed using energy dispersive spectroscopy (EDS) for CoCrW alloy after polishing

\begin{tabular}{lcccccccccccc}
\hline Region & $\mathrm{C}$ & $\mathrm{O}$ & $\mathrm{Si}$ & $\mathrm{V}$ & $\mathrm{Cr}$ & $\mathrm{Mn}$ & $\mathrm{Co}$ & $\mathrm{Sr}$ & $\mathrm{Nb}$ & $\mathrm{Mo}$ & $\mathrm{Ta}$ & $\mathrm{W}$ \\
\hline 1 & 3.98 & 0.26 & 0.51 & 1.76 & 23.16 & - & 59.63 & 1.35 & - & 0.85 & - & 8.50 \\
2 & 6.42 & - & 1.59 & 1.36 & 17.69 & - & 42.49 & 2.04 & 11.30 & 2.90 & - & 9.18 \\
3 & 3.10 & 30.64 & 19.40 & 1.08 & 16.31 & 2.15 & 15.12 & - & 2.68 & 0.5 & 6.29 & 2.45 \\
\hline
\end{tabular}

\section{Surface Characterization}

Scanning Electron Microscopy (SEM) and Energy Dispersive X-Ray Spectroscopy (EDS) Analysis

SEM and EDS analyses were made on a WDX600 0xford microscope (Leica Microsystems. Wetzlar, Germany) coupled to a Stereoscan 440 Leica scanning electron microscope (Leica Microsystems). The samples were polished using $1 \mu \mathrm{m}$ diamond paste, rinsed with water and etanol and air dried. Different surface regions were analyzed using EDS (Table 2).

\section{X-ray Photoelectron Spectroscopy (XPS) Analysis}

XPS analyses were made on a spectrometer (model XSAM HS; Kratos Analytical Ltd, Manchester, UK) under ultrahigh vacuum (about $10^{-8}$ Torr). Non-monochromatic $\mathrm{Mg} \mathrm{K}_{\alpha}(\mathrm{hv}=1253.6 \mathrm{eV})$ radiations were used as X-ray source, with $5 \mathrm{~mA}$ emission current at $12 \mathrm{kV}$ voltage. The samples were polished, rinsed with de-ionized water, cleaned in an ultrasonic bath with analytical grade acetone for $5 \mathrm{~min}$ and rinsed with de-ionized water. Previous to these experiments, the samples were immersed in artificial saliva and 0.15 mol.L $L^{-1} \mathrm{NaCl}$ solution for $8 \mathrm{~h}$ at $\mathrm{E}_{\text {corr. }}$ After $8 \mathrm{~h}$ the surface composition was analyzed to investigate the presence of cobalt ( $\mathrm{Co}$ ) and chromium ( $\mathrm{Cr}$ ) in the composition of the passive film. As binding energy reference was used the value $284.8 \mathrm{eV}$ for the carbon peak corresponding to the adventitious hydrocarbon (16). The evaluation included Shirley procedure for background subtraction, mixed Gaussian/Lorentzian function and a least-square routine for fitting the peak.

\section{Cytotoxicity Tests}

The cytotoxicity assay was carried out by exposing the cell culture to the solutions after contact with alloy samples, immersed for 10 days in culture medium MEM at $37^{\circ} \mathrm{C}$. The NCTC clone 929 cell line was acquired from American Type Culture Collection (ATCC) bank. The cytotoxicity effect was evaluated by neutral red uptake (NRU) methodology, described in previous papers $(17,18)$, according to the International Organization for Standardization (ISO) (19).

\section{Results}

\section{Electrochemical Results}

The corrosion potentials (stationary open circuit potential values) obtained for artificial saliva and 0.15 mol.L-1 $\mathrm{NaCl}$ solutions were $-100 \pm 28 m V_{\text {SCE }}$ and $-277 \pm 23$ $m V_{\text {SCE }}$ respectively (Fig. 1A). The anodic potentiodynamic polarization curves were obtained from corrosion potential and plotted in 
order to evaluate the effect of potential, to determine the potential range where the alloy is passivated and the value of the transpassivation potential. The chronoamperometric

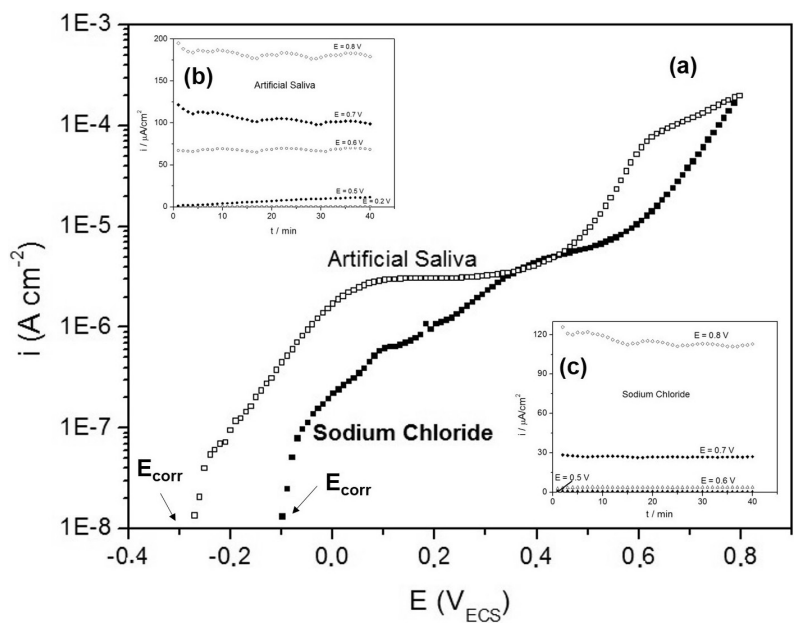

Figure 1. Potentiodynamic polarizations curves of CoCrW alloy in artificial saliva and 0.15 mol.L-1 sodium chloride at 37 oC. Panels $\mathrm{A}, \mathrm{B}$ and $\mathrm{C}$ show the chronoamperograms response at each potential application. tests were made in order to verify the presence or not of pitting corrosion on the passive film. The obtained results from polarization curves are plotted in Figure $1 \mathrm{~A}$ with the chronoamperometric curves at different potential values (Figs. 1B and 1C) for the alloy, in artificial saliva and $\mathrm{NaCl}$ medium, respectively. Chronoamperometric results are shown at different potentials and confirm those obtained by potentiodynamic polarization anodic curves, indicating the potential range where the metallic surface is passivated. The constant values of the current density observed at different potential values are an indication that the alloy does not present pitting corrosion.

EIS was employed to investigate the passive film/ electrolyte interface and evolution with increasing potential. Figure 2 shows Bode (modulus and phase) diagrams for CoCrW in artificial saliva (Fig. 2A) and 0.15 mol.L $^{-1} \mathrm{NaCl}$ solutions (Fig. 2B) at $\mathrm{E}_{\text {corr }}$ and $0.25 \mathrm{~V}_{\text {SCE. }}$. A similar behavior may be seen for the alloy/solution interface in both media: the imaginary and real components of impedance decrease as the potential becomes more positive than the $\mathrm{E}_{\text {corr }}$. The proposed equivalent circuit is presented in Figure $2 \mathrm{C}$, where $R_{s}$ correspond to the electrolyte resistance, $\mathrm{CPE}_{f}$ and $R_{f}$ correspond respectively to the constant phase element

\section{(b) Sodium chloride}
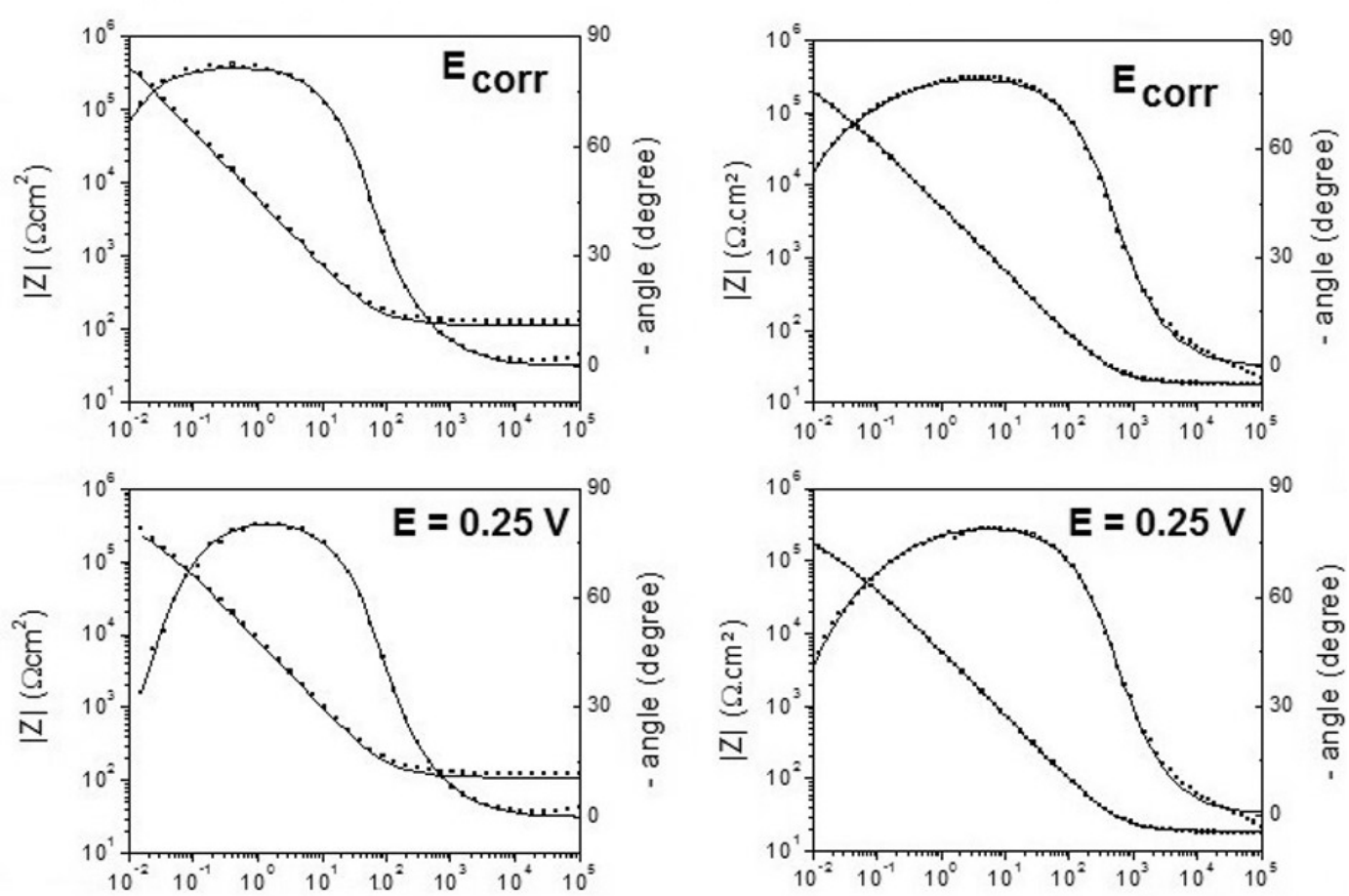

(c)

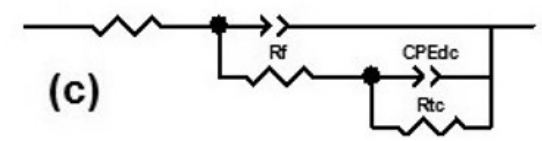

Figure 2. Impedance spectra of CoCrW alloy at sodium chloride (A) and artificial saliva. B: Bode plots registered at different potentials (Ecorr and $0.25 \mathrm{~V}) .(\bullet)$ experimental values, $(-)$ simulation. C: Electrical equivalent circuits used to fit the experimental data at different potentials. 
(pseudo-capacitance) and the polarization resistance for the oxidation reaction trough the protective film., $\mathrm{CPE}_{\mathrm{dc}}$ and $\mathrm{R}_{\mathrm{ct}}$ correspond, respectively, to the double layer constant phase element and the charge transfer resistance of the CoCrW alloy oxidation. The same circuit was proposed for $\mathrm{E}_{\text {corr }}$ and at $0.25 \mathrm{~V}_{\mathrm{SCE}}$ in both media.

\section{Surface Characterization}

SEM and EDS analyses were made to evaluate the existence of non-metallic inclusions. Different surface regions were analyzed using EDS after polishing with $1 \square \mathrm{m}$ diamond paste. Figure 3 presents three different regions, 1, 2 and 3 . According to EDS analysis the region 1 presents the bulk composition, region 2 corresponds to niobium carbides and region 3 is due to the presence of silicon and manganese oxides.

XPS was used to investigate the presence of $\mathrm{Cr}$ and Co in the composition of the passive film. Table 3 shows the absolute potentials of the components in the passive film. The chromium content of the surface is higher than cobalt in both media and is higher in 0.15 mol. $\mathrm{L}^{-1} \mathrm{NaCl}$ when compared to saliva. The results showed presence of chromium (III) and cobalt oxides in the passive film.

\section{Cytotoxicity Test}

Table 3. X-ray photoelectron spectroscopy (XPS) results for CoCrW alloy after immersed

\begin{tabular}{lcccc}
\hline & \multicolumn{4}{c}{ Bond Energy (eV) } \\
\cline { 2 - 3 } \cline { 5 - 5 } \cline { 4 - 5 } Cr 2p3/2 & & Co 2 p3/2 \\
\hline \multirow{2}{*}{$0.15 \mathrm{~mol} / \mathrm{L} \mathrm{NaCl}$} & $573.4(11 \%)$ & $\mathrm{Cr}(\mathrm{III})$ & $777.6(56 \%)$ & $\mathrm{Co}_{0 \mathrm{x}}$ \\
& $576.5(89 \%)$ & $\mathrm{Cr}_{0}$ & $780.2(44 \%)$ & $\mathrm{Co}^{0}$ \\
\multirow{3}{*}{ Artificial Saliva } & $573.1(11 \%)$ & $\mathrm{Cr}(\mathrm{III})$ & $777.2(53 \%)$ & $\mathrm{Co}_{0 \mathrm{x}}$ \\
& $576.2(89 \%)$ & $\mathrm{Cr}_{0}$ & $779.6(47 \%)$ & $\mathrm{Co}^{0}$ \\
\hline
\end{tabular}

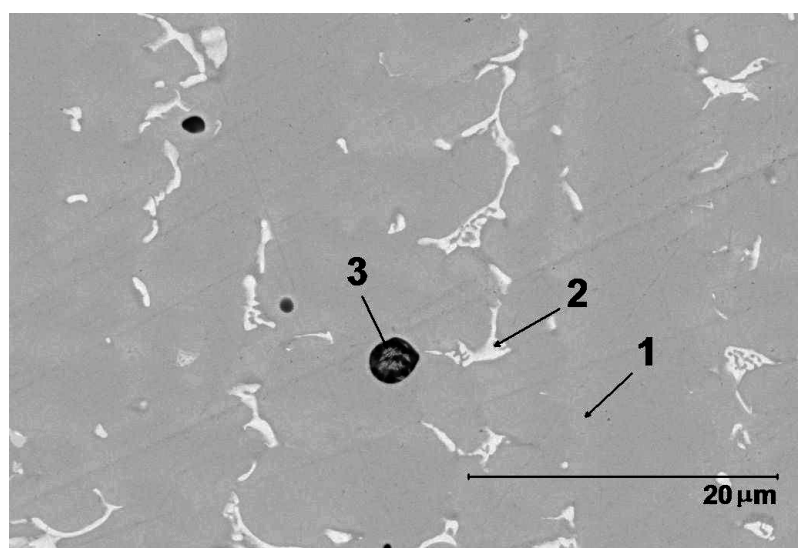

Figure 3. SEM and EDS images of CoCrW alloy samples polished through $1 \mathrm{~mm}$ diamond paste.
Cytotoxicity test was made and the results are in Figure 4 ; the cytotoxicity evaluation was performed by neutral red uptake assay. Positive and negative controls were used to confirm the adequate performance of the test procedure and/or to evaluate the results of CoCrW alloy, as well as to control the cell sensitivity, extraction efficiency and other test parameters. The sample that presents cell viability above the $\mathrm{IC}_{50}(\%)$ line is considered nontoxic and under the $\mathrm{IC}_{50}(\%)$ line it is toxic.

\section{Discussion}

Figure $1 \mathrm{~A}$ shows that the $\mathrm{E}_{\text {corr }}$ in saline solution is more positive, suggesting a better passive film formation when compared to artificial saliva medium. The CoCrW alloy (Fig. 1A) showed small values of current density ( 1 to $10 \mu \mathrm{A} /$ $\mathrm{cm}^{2}$ ) for a large analyzed potential range indicating good characteristics of the passive film formed in both media. The CoCrW alloy presents lower passivating current densities in $\mathrm{NaCl}$ medium, suggesting more passivating film for sodium chloride than in artificial saliva. The chronoamperometric curves (Figs. 1B and 1C) showed constant current density values even at high potentials, indicating the absence of pitting corrosion. The results have shown that $\mathrm{CoCrW}$ alloy presents only generalized corrosion at $0.9 \mathrm{~V}$ with high current density values in both media.

The characteristics of the passive film were investigated by EIS at $E_{\text {corr }}$ and $0.25 \mathrm{~V}_{\text {SCE. }}$. The results are presented in Figures $2 \mathrm{~A}$ and $2 \mathrm{~B}$. Bode phase diagrams are typical of passive systems with high values of both real and imaginary parts of the impedance at low frequencies. In the Bode diagrams the values of $|\mathrm{Z}|$ were about $10^{5} \Omega /$ $\mathrm{cm}^{2}$ and the angle greater than $75^{\circ}$, showing the high resistive and capacitive characteristics of the formed film. Bode phase diagrams point out to the same mechanism in artificial saliva and sodium chloride. Figure $2 \mathrm{C}$ also

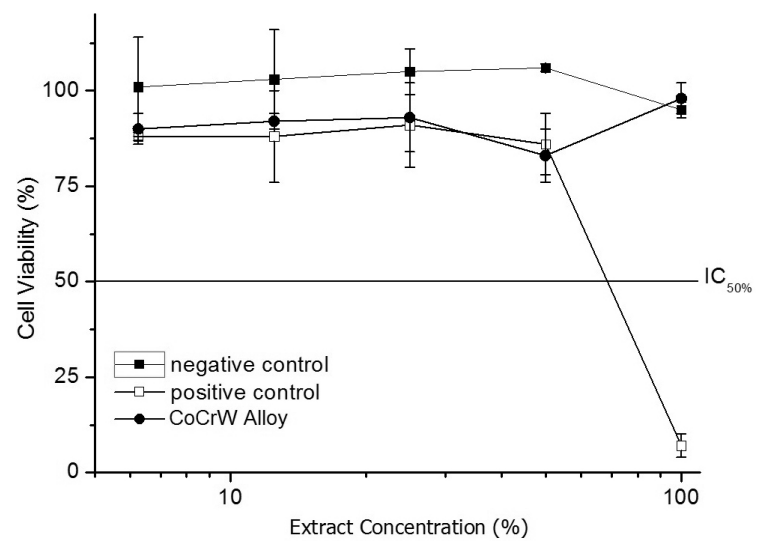

Figure 4. CoCrW alloy viability curves in the cytotoxicity assay by the neutral red uptake methodology. 
shows the fitting of the experimental results according to simulated equivalent circuits. Good agreement between the experimental results and the equivalent circuits proposed is observed on the entire range of studied frequencies, suggesting qualitatively the same mechanism in both media. The film formed in sodium chloride medium (Fig. 2B) has better quality than that formed in artificial saliva (Fig. 2A).

The composition of the passive film was analyzed by XPS at $E_{\text {corr }}$. The amount of chromium and cobalt in the passive film formed in sodium chloride is greater than in artificial saliva. The protective film is formed by chromium oxide in both media (20). These results were also obtained by Hodgson et al. (21). In CoCr-based alloys, only at high potential will be found another state of chromium oxidation, such as $\mathrm{Cr}(\mathrm{VI})(21,22)$. The chemical shift between $\mathrm{Co}^{2+}$ and $\mathrm{Co}^{3+}$ is very small (22-24), indicating a difficulty to characterize the oxidation state on the metallic surface. The low amount of cobalt in the film suggests that it diffuses into the solution and it does not significantly contribute to the oxide phase.

In this study the tested alloy did not present toxic effects even at 100\% extract concentration. All the viability curves are above the cytotoxicity index line, which means that the CoCrW alloy showed no cytotoxicity effects in this assay.

In this study the CoCrW alloy presented good behavior with the formation of a uniform passive film rich in chromium (III) oxide and a lower amount of cobalt oxides. The film formed in 0.15 mol. $\mathrm{L}^{-1} \mathrm{NaCl}$ is more capacitive and resistive than the one formed in artificial saliva. The chemical complexity of the artificial saliva probably contributes to greater instability of the passive film. SEM and EDS show that the CoCrW alloy presents niobium carbide and silicon and manganese oxides as non-metallic inclusions. Cytotoxicity tests validated the non-cytotoxic effect of the alloy according to the used methodology.

The results of this study suggest that CoCrW alloys from the electrochemical and cytotoxicity point of view may be used as biomaterials to be applied in prosthesis on dental implants.

\section{Resumo}

Estudos eletroquímicos, caracterização de superfície e teste de citotoxicidade in vitro foram realizados da liga $\mathrm{CoCrW}$ em meios de saliva artificial e $\mathrm{NaCl} 0,15 \mathrm{~mol}^{-\mathrm{L}^{-1}}$, com o objetivo de avaliar a sua aplicação como material de prótese dentária. Foram usadas como técnicas, curvas de polarização anódica, medidas cronoamperométricas, espectroscopia de impedância eletroquímica (EIE), microscopia eletrônica de varredura (MEV), espectroscopia por energia dispersiva de raios X (EDS) e espectroscopia fotoeletrônica de raios X (XPS). 0 teste de citotoxicidade também foi realizado. 0 comportamento eletroquímico da liga CoCrW foi comparado nos dois meios estudados desde o potencial de corrosão $\left(\mathrm{E}_{\text {corr }}\right)$ até uma sobretensão anódica de $600 \mathrm{mV}$. Foi observado, a partir de medidas eletroquímicas, que a liga CoCrW se encontra passivada em uma ampla faixa de potencial e que a sobretensões mais elevadas apresenta apenas corrosão generalizada nos dois meios. Análises por MEV e EDS mostraram que a liga apresenta inclusões não metálicas de carbeto de nióbio, de óxidos de silício e de manganês. Os resultados de XPS indicaram que o cobalto não contribui significativamente para a formação do filme passivo. 0 teste de citotoxicidade mostrou que a liga $\mathrm{CoCrW}$ não se apresenta citotóxica. Estes resultados sugerem que a liga estudada pode ser usada como biomaterial a ser aplicado como prótese sobre implantes dentários.

\section{Acknowledgements}

The authors acknowledge CNPq for the granted scholarship.

\section{References}

1. Anusavice KJ. Phillips materiais dentários, Guanabara Koogan, 10 ed., Guanabara Koogan, Rio de Janeiro; 1998.

2. Balamurugan $A$, Rajeswari $S$, Balossier G, Rebelo AHS, Ferreira RJMF. Corrosion aspects of metallic implants - an overview. Mater Corros 2008;59:855-869.

3. Bumgardner JD, Lucas LC. Cellular response to metallic ions released from nickel-chromium dental alloys. J Dent Res 1995;74:1521-1527.

4. Marananche $\mathrm{C}$, Hornberger $\mathrm{H}$. A proposal for the classification of dental alloys according to their resistance to corrosion. Dent Mater 2007;23:1428-1437.

5. Ameer MA, Khamis $\mathrm{E}, \mathrm{Al}-\mathrm{Motlaq} \mathrm{M}$. Electrochemical behaviour of recasting $\mathrm{Ni}-\mathrm{Cr}$ and $\mathrm{Co}-\mathrm{Cr}$ non-precious dental alloys. Corros $\mathrm{Sci}$ 2004;46:2825-2836.

6. Upadhyay D, Panchal MA, Dubey RS, Srivastava VK. Corrosion of alloys used in dentristry: a review. Mater Sci Eng 2006;432:1-11.

7. House K, Sernetz F, Dymock D, Sandy JR, Ireland AJ. Corrosion of orthodontic appliances - should we care? Am J Orthod Dentfac Orthop 2008:133:584-592

8. Ouerd A, Alemany-Dumont C, Normand B, Szunerits S. Reactivity of CoCrMo alloy in physiological medium: Electrochemical characterization of the metal/protein interface. Electrochim Acta 2008;53:4461-4469.

9. Contu F, Elsener B, Bohni H. Electrochemical behavior of CoCrMo alloy in the active state in acidic and alkaline buffered solutions. J Electrochem Soc 2003:150;419-424.

10. Wang $\mathrm{Q}_{\text {, Huang }}$, Z Zhang L. Microstruture and tribological properties of plasma nitriding cast CoCrMo alloy. J Mater Sci Technol.2012;28:60-66.

11. Hedberg YS, Qian B, Shen Z, Virtanen $S$, Wallinder IO. In vitro biocompatibility of $\mathrm{CoCrMo}$ dental alloys fabricated by selective laser melting. Dent Mater 2014;30:525-534.

12. Giacchi JV, Morando CN, Fornaro O, Palacio HA. Microstructural characterization of as-cast biocompatible CoCrMo alloys. Mater Charact 2011;62:53-61.

13. Karaali A, Mirouh $K$, Hamamda S, Guiraldenq P. Microstructural study of tungsten influence on Co-Cr alloys. Materials Mater Sci Eng A. 2005;390:255-259.

14. Karaali A, Mirouh $\mathrm{K}$, Hamamda S, Guiraldenq P. Effect of tungsten 0-8 wt.\% on the oxidation of Co-Cr alloys. Comput Mater Sci 2005;33:3743.

15. Leung VWH, Darvell BW. Calcium phosphate system in saliva-like media. J Chem Soc Faraday Trans. 1991;87:1759-1764.

16. Moulder JF, Stickle WF, Sobol PE, Bomben KD. Handbook of X-ray photoelectron spectroscopy. Chastain, J. Perkin-Elmer Corporation, Physical Electronics Division, Eden Prairie, MN, USA, 1992.

17. Rogero SO, Hilga OZ, Saiki M, Correia OV, Costa I. Cytotoxicity due to corrosion of ear piercing studs. Toxicol In Vitro 2000;14:497-504.

18. Jaimes RFW, Afonso MLCA, Rogero SO, Agostinho SML, Barbosa CA. New material for orthopedic implants: electrochemical study of nickel free P558 stainless steel in minimum essential medium. Mat Letts 2010;64:1476-1479.

19. Afonso MLCA, Jaimes RFV, Rogero SO, Nascente PAP, Agostinho SML. Surface characterization, electrochemical behaviour and cytotoxicity of UNS S31254 stainless steel for orthopedic applications. Mat Letts Volume 2015;148:71-75

20. Ossa CPO, Rogero SO, Tschiptschin APJ. Cytotoxicity study of plasmasprayed hydroxyapatite coating on high nitrogen austenitic stainless steels. J Mater Med 2006;17:1095-1100. 
21. International Organization for Standardization (ISO) 10993 - Biological evaluation of medical devices, Part 5: Tests for In Vitro Cytotoxicity, 2009.

22. Muñoz Al, Mischler S. Interactive effect of albumin and phosphate ions on the corrosion of CoCrMo implant alloy. J Electrochem Soc 2007; 154:562-570.

23. Hodgson AW E, Kurz S, Virtanen S, Fervel V, Olsson COA, Mischler S. Passive and transpassive behavior of $\mathrm{CoCrMo}$ in simulated biological solutions. Trans Nonferrous Metals Society of China 2004:49:2167-
2178.

24. Milosev I, Strehblow HH. The composition of the surface passive film formed on CoCrMo alloy in simulated physiological solution. Electrochim Acta 2003;48:2767-2774.

Received September 5, 2015 Accepted January 7, 2016 